\title{
A Well-Married Landscape: Networks of Association and 6th-Century Communities on the Isle of Wight
}

\author{
Sue Harrington
}

That women are by and large 'hidden from history' is an obvious statement, a consequence of texts being produced for purposes from which, it is inferred, they were uninvolved in or excluded from or at least did not have their contribution acknowledged. ${ }^{1}$ To quote Gillian Clarke "We are, as usual, trying to interrogate the writings and artefacts of men for information it never occurred to them to give." ${ }^{2}$ Accordingly, to find women in the past from historical sources, one has to read beyond the small volume of evidence to establish, beyond a few named individuals, the existence of the female population. Whilst it would be tedious to reiterate and bewail the masculinist content of the king lists and other documents from that period, Barbara Yorke's work on the early AngloSaxon kingdoms raises one's hopes that meaningful lives of contemporary women can be illuminated. By aligning feminist perspectives on archaeology with approaches from social geography in conceptualising space, place and gender, ${ }^{3}$ and considering elements of the archaeological record as a form of social network, different perceptions of the cultural dynamics of the mid-first millennium AD might be foregrounded. An appraisal of source material is required, both 7 th-century historical and earlier archaeological, in order to tease out aspects of attitudes to and the position of women in the sixth century in Britain.

This paper was prompted by two factors: firstly, Barbara Yorke's presentation on the mid-6th-century female from Chessell Down grave 45 at the UCL Institute of Archaeology conference, Women's Work: Archaeology and the Invisible Sex (2000). This encouraged me to reflect that by acknowledging my wariness regarding historical sources, a reappraisal of the intersections with archaeological research would be fruitful. Secondly, her comments on the role of women in the power struggles and strategies in the formation of the Kentish kingdom,

1 Sheila Rowbotham, Hidden from History (London, 1974).

2 Gillian Clarke, Women in Late Antiquity: Pagan and Christian Lifestyles (Oxford, 1994), p. 3.

3 Doreen Massey, Space, Place and Gender (Cambridge, 1994). 
formed a glimpsed narrative of gender issues in the 7 th century - with outcomes that could be investigated via the archaeology of the 6th and which will be expanded upon in this paper. ${ }^{4}$

\section{Women in Early Anglo-Saxon Studies}

Within Anglo-Saxon archaeology the impact of feminist-derived gender research has been minimal in comparison to its impact on prehistory. Sam Lucy asserts that this was a function of the historicist tradition of Anglo-Saxon scholarship, rather than through any inherent problems with the archaeological data per se. ${ }^{5}$ Much of the early discussion on the role of women in the early medieval period has focused on marriage and the domestic context. ${ }^{6}$ Stenton notes only individual abbesses and queens, with no index entries for the category 'women.' 7 This absence of meaningful focus sits uneasily perhaps with the acknowledged attributes of women to hold land in their own right and to act as compurgators in law-suits. ${ }^{8}$ This later attribute, of acting as a witness who could swear to the innocence or good character of an accused person, places women in the role of reliable truth-sayers. Immediately one wonders if this role might relate to a much earlier role in divination, evidenced by amulets, curing stones and crystal balls found exclusively in female graves of the 6th century. ${ }^{9}$ Perhaps this is just another example of an archaeologist's leap based on shaky understandings of the texts, but does suggest that the concept of 'woman' had a cultural value within a set of idealised gender qualities, rather than individual attributes, that had clear social and political purpose.

A quotation from the late Martin Welch's text-edited at this point by Barbara Yorke-on the documentary sources for the early Anglo-Saxon kingdoms in southern Britain, is worth quoting at length here: ${ }^{10}$

4 Barbara Yorke, Kings and Kingdoms of Early Anglo-Saxon England (London, 1990), pp. 25-44.

$5 \quad$ Samantha Lucy, "Housewives, Warriors and Slaves?" in Invisible People and Processes, ed. Jenny Moore and Eleanor Scott (Leicester, 1997), pp. 150-68 at p. 150.

6 Dorothy Whitelock, The Beginnings of English Society (Harmondsworth, 1952), pp. 93-95.

7 Frank M. Stenton, Anglo-Saxon England, 2nd ed. (Oxford, 1947). In the third edition (1971), there is a single page index listing for "women, their contribution to monastic reform."

8 Whitelock, The Beginnings of English Society, p. 94.

9 Audrey Meaney, Anglo-Saxon Amulets and Curing Stones, BAR British Ser. 96 (Oxford, 1981).

10 Martin Welch (ed. Barbara Yorke), "The Kingdoms in the Written Sources," in Sue Harrington and Martin Welch, The Early Anglo-Saxon Kingdoms of Southern Britain, AD 450650: Beneath the Tribal Hidage (Oxford, 2014), p. 3. 
The many journeys between southern England and Francia recorded for church members can be taken as representative of a much broader and well-established traffic. In the same way emulation of Frankish family monasteries, and particularly the tendency for these to be run by princesses and other high status women, may be an indication of a wider and longer-rooted Frankish influence on elite life.

A second observation from the same project is also pertinent. Martin Welch noted - a point endorsed by Barbara - that territorial boundaries were subject to frequent revision. This was particularly the case with territories on the periphery of kingdoms exemplified by the changing control of the Isle of Wight, a matter commented on by Bede (HE IV.15-16).

Barbara Yorke notes elsewhere that king Æthelberht's sister Ricula was married to Sledd of the East Saxons and that "Kent played a role in bringing the family to power."11 So, it can be inferred that the presence of this Kentish representative was a visible statement, an example of the symbolism of a wider power made apparent by the female body. Whilst Æthelberht agreed to convert to Christianity as a condition of his marriage to Bertha of Francia, but actually converted via Rome not through his bride's Christian entourage-was this sidelining her symbolic representation of the power of the Franks, and in what position did this place her, both as a person and as a cipher? This very action represented a loosening of existing ties with Francia and an assertion of regional independence. Nevertheless, a repeat transaction saw Æthelberht's son Eadbald, whose mother was Bertha, marry another Frankish bride, Ymme, repeating the strategy of a networked power association-demonstrating a need to maintain these cross-channel links and by extension the links of the Frankish network throughout Europe. Indeed, the marriage of Eadbald in the first instance to his step-mother (his father's second wife), ${ }^{12}$ perhaps is an indication of the real issue at play - the political power this union signified for the kingdom of Kent, or at least the presentation of such an on going alliance to other emergent kingdoms in the island of Britain.

However, was this only one way traffic or were value transactions involved as a trade-off, such as land grants, tribute revenues and access to trading links? Sonia Chadwick Hawkes, highlighting the presence of bridal females with gold

11 Yorke, Kings and Kingdoms, pp. 28-29.

12 Kenneth P. Witney, "The Kentish Royal Saints: An Enquiry into the Faces Behind the Legends," Arch. Cant. 101 (1984), 1-22, at p. 2. 
braided head-dresses buried in Kent, certainly assumed this to be the case. ${ }^{13}$ Barbara Yorke demonstrates the value of female relatives at a variety of levels, sometimes with repeat marriages within the same family to hold the link fast. ${ }^{14}$ But a new role, for high status women at least, is evident in the 7 th century, as abbesses within newly founded monastic institutions. In summarising this situation Barbara notes that, for example "control of Minster[-in-Thanet] ... passed among female members of the royal house" and that "abbesses were active in gaining grants and privileges." 15 Indeed here is the crux of this discussion:

The proprietary houses may also have been linked with the administration of the kingdom for a number of them seem to have been based in the central places of major estates for whose spiritual needs they would have been responsible.

Was this linkage between elite female status and land holding or administration a new development of the 7 th century or a continuation of earlier practices? How might a marriage brokerage system sit within a developing social context, however one that perhaps still relied on the symbolic value of women to make it viable? How did this situation come about? Or was this a continuation of a tradition of venerating high status women, now presumed to be religious because of their elite connections?

John Blair proposes that "in the pioneering stages of the English conversion ... women may have played a dynamic role which faded when institutional structures crystallized."16 $\mathrm{He}$ also conjectures on the appeal of Christianity to pagan women, as it gave them the opportunity for the "heroic afterlife that their warrior husbands could expect." I would argue conversely that the very rich nature of female burials in the 6th century does actually reflect a similarly elevated set of afterlife concepts, but one that, alongside contemporary male burials, was also fixed in their present, as an aide mémoire to the living within the landscape. ${ }^{17}$

13 Sonia Chadwick Hawkes, "Anglo-Saxon Kent c.425-725," in Archaeology in Kent to 1500, ed. P. Leach, Council for British Archaeology Research Report, 48 (London, 1982), pp. 64-78.

14 Yorke, Kings and Kingdoms, p. 37, table 3.

15 Yorke, Kings and Kingdoms, p. 38.

16 John Blair, The Church in Anglo-Saxon Society (Oxford, 2005), pp. 174-75.

17 Howard Williams, Death and Memory in Early Medieval Britain (Cambridge, 2006), p. 178. 


\section{Marriage at All Ages?}

Witney notes that women could not take the veil and enter a convent as a nun until the age of $16 .{ }^{18}$ This could have a practical outcome in that there might be a saving on a dowry by the girl's family and would keep property that might be diverted within the family. ${ }^{19}$ There is sufficient archaeological evidence that can be interpreted to suggest that pre-Christianity females could be married before this age and buried with full adult female assemblages - the girl, indicated age of c.10 years from Holywell Row grave 11, Suffolk and illustrates this point, as does the potentially younger girl from Buckland Dover grave $20 .{ }^{20}$ The following examples are all from bodies sexed skeletally as female but with burial material that is most commonly associated with young adult and adult women. They span the 6th and 7 th centuries. It must be acknowledged that there is an issue with the circularity of ascription wherein the gender of feminine grave material is then inscribed onto the sex of the body, where none may have survived, and the resolution of sex queries being subordinated to the gendering of the objects. ${ }^{21}$

There was an infant (age at death 0-2 years) of the later 6th century, with beads, a Kentish/Frankish buckle and a style II bracteate from grave 40 in the unpublished site at Ozengell, Kent (author's research notes) and another in grave 86 with a keystone garnet disc brooch. In contrast there is only one example of a male associated weapon-a D1 spearhead — with such a young body, in this case in grave 89 from the unpublished Kentish site at Bradstow School, Broadstairs. One can also pick out children placed in the age at death category of 3-6 years with adult type material. Finglesham, Kent grave 7 , dated to the second half of the $7^{\text {th }}$ century, has wheel-thrown vessels and gold pendants and Sarre, Kent grave 277 dated to the 7 th century, has a set of keys. ${ }^{22}$

Within the next age at death category, that of Juvenile $7-15$, there are a greater number female bodies with adult feminine assemblages. Following the

18 Witney, “The Kentish Royal Saints," p. 3.

19 Clarke, Women in Late Antiquity, p. 53, discussing Roman elites.

20 Thomas C. Lethbridge, Recent Excavations in Anglo-Saxon Cemeteries in Cambridgeshire and Suffolk, Cambridge Antiquarian Society Quarto Publication 3 (Cambridge, 1931); Vera I. Evison, Dover, the Buckland Anglo-Saxon Cemetery (London, 1987).

21 Lucy, "Housewives, Warriors and Slaves?"; Nick Stoodley, The Spindle and the Spear: A Critical Enquiry into the Construction and Meaning of Gender in Early Anglo-Saxon Inhumation Burial Rite, BAR British Ser. 288 (Oxford, 1999).

22 Sonia Chadwick Hawkes and Guy Grainger, The Anglo-Saxon Cemetery at Finglesham, Kent, Oxford University School of Archaeology Monograph, 64 (Oxford, 2006); David Perkins, "The Jutish Cemetery at Sarre Revisited: Part 2," Arch. Cant. 110 (1992), 83-120. 
work of Nick Stoodley, the age of 12 appears to be that at which girls were perceived to be ready for marriage and, one assumes, for childbearing. ${ }^{23}$ These examples occur throughout the late 5 th, 6 th and 7 th centuries of furnished burial- examples amongst many are Saxton Road grave 51 with beads and button brooches, Portway Andover graves 44 and 61 with beads and chatelaines and Long Wittenham grave 7 with pierced coins and a range of beads and pendants on her necklace. In this age grouping male bodies with weapons become present. The juveniles with swords are the most obvious (Saxton Road grave 42, Croydon grave 4, Dover Buckland grave 21 and Bradstow School grave 71), but there are also 48 examples of young male bodies with spearheads. This age correlation has already been investigated by Heinrich Härke, so it serves only to note here the parallel nature of the cultural trait of vesting young male bodies with older age-related material. ${ }^{24}$ In summary, it is plausible to suggest that the wide temporal span of these graves may indicates that the practice of embellishing female children with adult female assemblages continued throughout the period of Christianisation and thus may well have been a long and deeply embedded cultural practice.

Within this age group there are also examples of female-associated cultural material that is not local to the region of burial. For example Dover Buckland grave 326 has a pair of Anglian wrist clasps in situ, items that are rare in southern Britain, with only eight published examples. ${ }^{25}$ Kent, although with the largest number of recorded excavated graves, shows surprisingly few artefacts that were culturally non-local. ${ }^{26}$ However, there is a greater frequency, in contrast, of Kentish material outside of Kent: 66 brooches appear throughout southern Britain, although only a few with the under-15 age group.

\section{Non-local Cultural Material}

Just considering brooch types in the Kentish kingdom, the Saxon saucer brooches (27 examples) that do occur within East Kent are all at major sites such as Faversham, Lyminge and Dover Buckland, but not elsewhere in the

23 Stoodley, Spindle and the Spear; "Burial Rites, Gender and the Creation of Kingdoms: The Evidence from Seventh-Century Wessex," ASSAH 10 (1999), 99-107.

24 Heinrich Härke, "Early Saxon Weapon Burials," in Weapons and Warfare in Anglo-Saxon England, ed. Sonia Chadwick Hawkes (Oxford, 1989), pp. 49-61; Heinrich Härke, Angelsachsische Waffengraber Des 5. Bis 7. Jahrhunderts (Cologne, 1992).

25 Keith Parfitt and Trevor Anderson, Buckland Anglo-Saxon Cemetery, Dover. Excavations 1994, The Archaeology of Canterbury, New Ser., 4 (Canterbury, 2012).

26 Harrington and Welch, The Early Anglo-Saxon Kingdoms of Southern Britain. 
communities east of the Medway. The small long brooch, culturally designated at Anglian and a rather common item, is more widely spread amongst sites east of the Medway, but relatively infrequent in West Kent. A child aged at death 3-6 years with two Anglian type small long brooches was in grave 254 at Dover Buckland. ${ }^{27}$ Outside of Kent the situation appears to be different. Brooch wearers up to the age of 15 have very few Kentish brooches. Indeed, there are more penannular brooches with these young females (16 examples) than any other putatively non-regional types. The penannular brooch also occurs in Kent too. How might these distributions be interpreted? Can we see here the movement of young females out of Kent but a much more limited presence of non local women within it? Do the regions and polities further to the west of the Anglo-Saxon communities also employ a strategy of linkage through females and over considerable geographical distance? This of course begs the question around whether objects move, as trade goods or 'fashion' items, or whether the females move and carry the cultural material with them. The latter argument is favoured.

This somewhat cursory exploration of the archaeological evidence does nevertheless add weight to the proposition that the strategic exchange of females of all ages before and after puberty could explain these patterns of distribution of culturally specific artefacts in the $5^{\text {th, }} 6$ th and, briefly, $7^{\text {th }}$ centuries. Inevitably, more questions are raised than can be addressed adequately here. However, whilst this exogamic movement of women is highlighted through the burials of young females, ${ }^{28}$ one must also assume that the burials of older women (married early but living longer) may well illustrate crucial aspects of this socio-political mechanism. This cultural trait appears, in southern Britain at least, before the advent of female involvement in the religious institutions of the $7_{\text {th }}$ century. This later process, although still hiving off females, perhaps into locales away from their kin group, itself an exogamous process, but one that still retained them within their elite group and as representatives of it.

What can analysis of their complex burial assemblages from disparate cultural sources indicate about their life courses and role in the dynamics of territorial expansion that characterised the early kingdoms? The basis of the discussion that follows is to suggest that the females accumulated cultural material throughout their life courses (however brief) and that that material is

27 Anderson, Buckland Anglo-Saxon Cemetery.

28 Sue Harrington, "Beyond Exogamy," in Studies in Art and Archaeology: Papers in Honour of Martin G. Welch, ed. Sue Harrington, Andrew Reynolds and Stuart Brookes, BAR British Ser. 527 (Oxford, 2011), pp. 88-97. 
indicative of cultural networks across space. That this material came to be fixed within a landscape context is suggested to be diagnostic of the processes of state formation in the mid-6th century in southern Britain. Here, one draws towards the intricacies of gender and landscape and the discussion now focuses on the theme of the precursor (6th-century) power network facilitated by female mobility within the territoriality of landscapes.

\section{Gender and Social Dynamics}

The case study used to explore these propositions is the woman from grave 45 at Chessell Down on the Isle of Wight and her contemporaries. But first, it is important to establish the theoretical standpoint that will inform the discourse. Gender identity, from burials in early Anglo-Saxon England, appears to relate to wealth and status, with common correlates of women with jewellery and men with weapons. This is certainly too coarse a classificatory method, as has been pointed out. ${ }^{29}$ Gender, or the socially constructed element of identity, is not a fixed and universal trait and can be seen evolving within dynamic contexts. ${ }^{30}$ Gender is an arena for subtle short term and dynamic longer term changes in human agency and identity and is deeply connected to societal change, particularly as it engages with economic activity. This is particularly obvious in Anglo-Saxon contexts that associate unmarried females with spinningas spinsters - an identity confirmed within an economic context of surplus production of the key commodity of cloth. ${ }^{31}$

Gender as an area for research is very much concerned with agency, work, nuance, life course, dynamic change and power relationships, intercut with changing hierarchies and beliefs. What burial can offer to understandings of gender is a snapshot of a cultural situation that has been set in time and space. Additionally, issues of space and place and how these might interact with gendered lives have long been a concern of social geographers, particularly second wave feminists such as Doreen Massey and Gillian Rose, with a shift in emphasis to think about the spatial in terms of social relations and the forms of knowledge that this might entail. ${ }^{32}$

\footnotetext{
29 Lucy, "Housewives, Warriors and Slaves?"; Stoodley, Spindle and the Spear; "Burial Rites, Gender and the Creation of Kingdoms."

30 Roberta Gilchrist, "The Spatial Archaeology of Gender: A Case Study of Medieval English Nunneries," Archaeological Review from Cambridge 7:1 (1988), 21-28.

31 Chris Wickham, Framing the Early Middle Ages: Europe and the Mediterranean, 400-80o (Oxford, 2005), p. 700.

32 Massey, Space, Place and Gender, p. 19.
} 


\section{The Cemetery at Chessell Down, Isle of Wight, and Grave 45}

To return to the Chessell Down burials on the Isle of Wight- - here given the shorthand code of CLD. The site of the Chessell Down cemetery, now within a Forestry Commission conifer plantation, is on the western end of the island on the northwest slope of chalk downs at $114 \mathrm{~m}$ above sea level, in the parish of Shalfleet. The aspect of the slope is interesting, as it offers a wide view westwards over the sea approaches to the Solent and to any landing places on the mainland shore opposite in Hampshire. The cemetery is one of many along the central chalk ridge of Wight (the project database records twelve sites), mainly only excavated partially, but consistently producing material linking these communities to Kent in the 6th century. The place name Chessell may derive from OE ciest, 'chest or coffin', combined with hyll, 'hill', suggesting local awareness over time of the presence of this burial ground. ${ }^{33}$ The site overlooks a north-south low level routeway between the chalk downs across the island that links the routeway along the foot of the scarp and the channel facing coast to the south. Any traveller coming off the downs from a higher level routeway would have passed through the cemetery to reach the other roads and tracks. On the corresponding hill, facing eastwards is the barrow cemetery at Shalcombe Down, with secondary Anglo-Saxon inhumations and a possible cremation. Amongst the grave goods are a sword and poor quality imitations of Kentish keystone garnet disc brooches suggesting knowledge of the brooch type but without the necessary craft skills to reproduce them accurately. ${ }^{34}$

Although the two burial grounds are seemingly very close and in visual proximity, the distribution of cemeteries along and around the chalk ridge of the Isle of Wight mirrors the density found in Kent and other downland settled areas. The majority of the diagnostic material in Isle of Wight cemeteries of the 6th century comes from Kent or Francia, with Frisian pottery also present. From further afield, there is a Visigothic tremissis of AD 509 to 520 at Bowcombe Down and embossed rim copper alloy bowls from the Rhineland. The recently published metal detected find of a Frankish helmet from a weapon grave on Bowcombe Down exemplifies the cross-Channel links in that period. ${ }^{35}$ The Portable Antiquities Scheme database records a very similar mix of

33 Christopher J. Arnold, The Anglo-Saxon Cemeteries of the Isle of Wight (London, 1982), p. 18, referencing Helge Kökeritz, The Place-Names of the Isle of Wight (Uppsala, 1940), p.209.

34 Arnold, The Anglo-Saxon Cemeteries of the Isle of Wight, pp. 81-83.

35 James Hood et al., "Investigating and Interpreting an Early-to-Mid Sixth-Century Frankish Style Helmet," British Museum Technical Research Bulletin 6 (2012), 83-95. 
material in the area below Chessell Down. Another penannular brooch (Fowler type $G$ ) has also been found in the locality.

The confused and piecemeal excavation of Chessell Down by antiquarian diggers in the 19 th century needs not be reprised here, ${ }^{36}$ suffice to comment that this was a large and important site whose archive eventually found a secure home in the British Museum. All available evidence was eventually reconstructed by Arnold from the disparate sources, with the caveat that the evidence was eccentric so that the grave groups as published must constitute a 'best guess' rather than definitive statements-his list includes over 200 unassociated items. The profile of the material found from cemeteries on the Isle of Wight and collated by Arnold shows material broadly datable to the 6th century. There is very little that is Saxon or Anglian in origin, with only a few applied disc brooches and Swanton type L and J spearheads. ${ }^{37}$ It is notable that the main spearhead types (from the H series) are not frequent in East Kentish contexts. There is also a penannular brooch from the British West.

The original extent of the cemetery was probably much greater than as excavated, with many graves situated around the edge of marl pits that had eaten into the hillside. Nevertheless, a conservative estimate of the number of people whose graves could be identified runs in excess of 110, placing it in terms of scale commensurate with the contemporary Kentish sites. The presence of cremations was also noted, but it is uncertain here from the published evidence if these are actually contemporary or much earlier. ${ }^{38}$ Mixed rite cemeteries are rare in Kentish type sites, but are more frequent elsewhere. ${ }^{39}$ Another unexpected feature is the use of stone lined cists, of which there are two examples noted (although there may be some ambiguity in the antiquarian use of the term, it is assumed that a stone-lined chamber is indicated). Again these are generally found outside of Kent and were used from the Late Roman period onwards in areas at the upland edges and beyond the regions of Anglo-Saxon settlement. CLD Grave 45 is described thus: "the cist was about eight feet in length and nearly five in width. The skeleton was on its back, and betokened a person in life of stately presence." 40 Grave 8 , the other cist, is much less substantially constructed and contained only an iron knife. From the reconstructed site plan CLD 45 lies at the end of a row of graves all orientated north east to south west (the line is discontinued by the edge of a marl pit). ${ }^{41}$ Those to the

36 Arnold, The Anglo-Saxon Cemeteries of the Isle of Wight, pp. 13-19.

37 Michael Swanton, A Corpus of Anglo-Saxon Spear Types, BAR British Ser. 112 (Oxford, 1974).

38 Arnold, The Anglo-Saxon Cemeteries of the Isle of Wight, p. 18.

39 Harrington and Welch, The Early Anglo-Saxon Kingdoms of Southern Britain.

40 Arnold, The Anglo-Saxon Cemeteries of the Isle of Wight, p. 26.

41 Arnold, The Anglo-Saxon Cemeteries of the Isle of Wight, Fig. 3. 
south of CLD 45 in the line are unfurnished burials (graves 46, 47, $5^{\circ}$ and 52 ) with the exception of a south east to north west orientated spear grave (48).

The plan of grave 45 is an image used very frequently to illustrate a female burial in the 6th century, almost as an archetype, although in the context of her contemporaries she is clearly unusual. The plan is George Hillier's original drawing, made more widely known through inclusion in volume vi of Charles Roach Smith Collectanea Antiqua (1868) and latterly Chris Arnold's volume (1982) on the Anglo-Saxon cemeteries of the Isle of Wight (Fig. 5.1). Yet, how accurate a depiction is it? The slightly ghoulish representation of the skull and disproportionately long legs within a distracting etched background tends to mask the extraordinary visual nature of her assemblage and denotes her as exceptional rather than as representative of women in the 6th century. We have no personal information about her, apart from inferring a fully grown body and what the assemblage might suggest about her life-course. The types of objects associated with her and their provenances are given in Table 5.1, below.

She has a more extended range of artefact provenances than other contemporary females, with her gold braid, Frankish style dress fitments, Kentish brooches and the Kentish-type weaving beater. As Barbara Yorke originally suggested some years ago, she appears to be conventionally Kentish in aspect, but may well have come from Francia, perhaps as a point of origin and indicated by the gold braid, but subsequently via Kent. Her final destination and purpose was to demonstrate the affiliations of the Isle of Wight to Kentish and Frankish trading interests. There is nothing overtly Scandinavian in her material culture, however, in contrast to her mid-6th-century contemporary in grave 4 at Sarre, Kent. Sarre 4 has a parallel assemblage, but one that also includes southern Scandinavian type gold bracteates. It is tempting to suggest that both women, Sarre 4 and CLD 45, arrived in Kent from different locales, gathering personal material as they were moved. Her three great square-headed brooches are culturally Kentish, but are made of silver - a relatively rare raw material that could have come either from Francia or conceivably traded from on-going mine workings in the British West. The weaving batten has for many years been discussed as a tool for use on the warp weighted loom. ${ }^{42}$ It is now proposed that, with its particular form, associated contexts and relatively short temporal span of use, it had a less utilitarian function and may rather relate to regulation

42 Marta Hoffmann, The Warp-Weighted Loom, Studia Norvegica 14 (Oslo, 1964); Louise Millard, Shirley Jarman, and Sonia Chadwick Hawkes, "Anglo-Saxon Burials near the Lord of the Manor, Ramsgate: 17-22," Arch. Cant. 84 (1969), 9-32. 


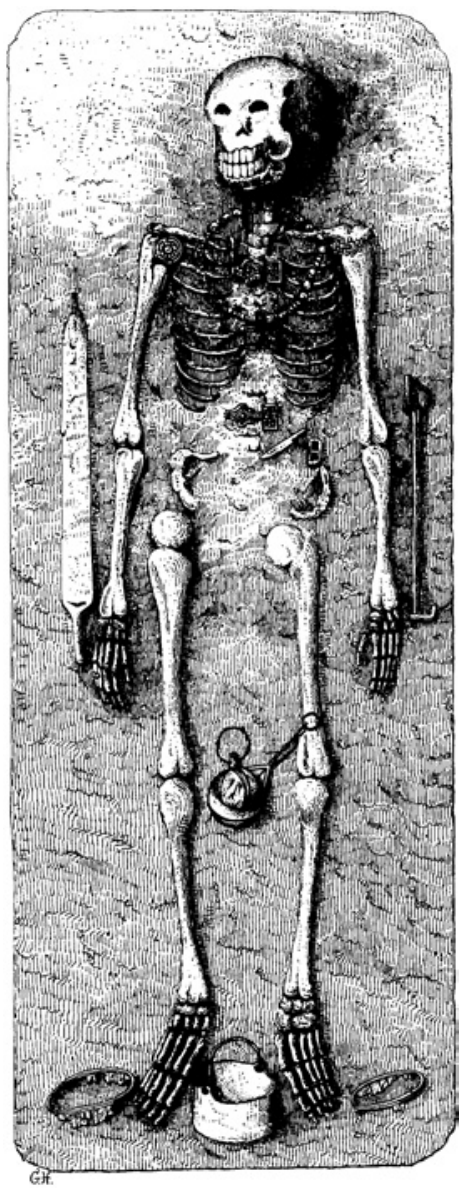

FIGURE 5.1

Grave 45 Chessell Down, from Williams, Death and Memory, Fig. 1, p. 7

of cloth widths for trade and tribute. ${ }^{43}$ This assertion would place this object on a par with weapon swords, if they themselves are seen as emblematic of a royal official such as a port reeve, charged with obtaining dues from trading activities along the coast. It is noted that weaving battens do not occur in cemeteries unless there is a contemporary sword burial as is the case with Chessell Down (nine swords in graves plus another five unassociated examples).

CLD 45 was not alone within her community in her geographically distant contacts. Another eight females in the Chessell Down cemetery (where grave groups have been established: that is graves 3, 13, 23, 40, 69, 98 and 108) had Frankish type brooches. Does this group perhaps suggest an entourage of

43 Sue Harrington, "Early Anglo-Saxon Weaving Swords Revisited," in The Evidence of Material Culture: Studies in Honour of Professor Vera Evison, ed. Ian Riddler, Jean Soulat, and Lynne Keys (Autun, 2016), pp. 209-18. 
TABLE 5.1 CLD 45's objects and their provenances

\begin{tabular}{lll}
\hline Object & Material & Provenance \\
\hline Pail/bucket with runic inscriptions & Copper alloy & Eastern Mediterranean \\
Perforated spoon & Silver & Via Kent \\
Crystal ball & Crystal & Via Kent \\
Latch lifter/girdle hanger & Iron & Local or via Kent \\
Cup(s?) & Wood with decorated silver & Via Kent? \\
Knife & Iron & Local \\
Buckle loop & Iron with silver inlay & Frankish \\
Great Square headed brooches $\times 3$ & Silver gilt, garnet & Kentish \\
Symmetrical brooch & Silver gilt, garnet & Kentish/Frankish? \\
Keystone garnet disc brooch & Silver gilt, garnet & Kent \\
Braided headband & Gold thread & Frankish? \\
Beads & & Various \\
Weaving batten & Iron & Kentish \\
Finger ring & Gold & Unknown \\
Finger ring & Silver & Unknown \\
\hline
\end{tabular}

females, possibly an entire household or kin group? Gillian Clarke comments that 'If an important woman in a household took to the ascetic life, her women relatives, dependents and slaves might join her, so that the household became a community'.44 Life on the Isle of Wight in the 6th century, however exposed to gales from south westerly winds and strong sea currents, does not necessarily imply asceticism and isolation, but such a grouping together of women may have strengthened the bonds of this outpost to the local community of traders and back to their Kentish and Frankish elites, as was the custom.

Is there any reason to suppose that CLD 45 herself may have come from further afield? Hackenbeck et al. demonstrated through stable carbon and nitrogen isotope analyses of bone from the mid-5th- to mid-7th-century community of Altenerding in Bavaria, that the diet of women indicated greater mobility than that for men and that there were correlates with 'foreign' grave goods, in the case of grave 421 from Scandinavia. ${ }^{45}$ Curiously, the woman in grave 343 at Altenerding with a weaving sword had a distinctively low nitrogen

\footnotetext{
44 Clarke, Women in Late Antiquity, p. 102.

45 Susanne Hackenbeck et al., "Diet and Mobility in Early Medieval Bavaria: A Study of Carbon and Nitrogen Stable Isotopes," American Journal of Physical Anthropology 143:2 (2010), $235^{-49}$.
} 
score in contrast to the rest of her community. Such analyses have not been carried out for the skeletal material that survives from Chessell Down, so any inferences about wider mobility must be drawn from the artefactual evidence.

The pail in grave CLD 45 is a rare artefact, provenanced to the eastern Mediterranean. Whether it can be argued that she arrived via the eastern Mediterranean with her decorated pail is a moot point, but it is noted that these particular objects do not occur along the overland and riverine routes of mainland Europe. ${ }^{46}$ Eastern Mediterranean-sourced artefacts, such as weighty copper alloy bowls, appear in Kent from the late 6th century onwards. It is interesting to speculate whether more extensive trading routes along the western seaboard of Britain and northern France had been established by then - the wealth of Kentish material, including a weaving beater of similar form to that with CLD 45, from the cemetery at Herpes-en-Charente, France, from mid-way down the Bay of Biscay, may point to this. In this case, a differentiation might be made between those artefacts of personal adornment, such as brooches accrued during her life course and in recognition of her cultural affiliations and role in formal alliances, and given artefacts, such as the weaving batten and the pail that manifested hers and her community's wider associations.

There is a small concentration of eastern Mediterranean material in Wight, Hampshire and Sussex a generation or more earlier than it appears in Kent. The glass vessel from grave 49 at Highdown, West Sussex may be broadly contemporary with the deposition of the mid-5th-century Patching Hoard. ${ }^{47}$ The decorated pail from grave 1 at Shallow's Farm, Breamore in a double burial has close similarities in terms of its decorative scheme with the Chessell Down item..$^{48}$ The find of bridle fitment first alerted investigators to the presence of early Anglo-Saxon material near a crossing point of the river, ${ }^{49}$ yet this was an object that came too from the eastern Mediterranean.

The Shallow's Farm burial was a double male/female inhumation with both bodies covered by a shield boss and with a ferruled spearhead. It is noted that

46 Anthea Q. Harris, Byzantium, Britain and the West, the Archaeology of Cultural Identity (Stroud, 2003).

47 Martin Welch, Early Anglo-Saxon Sussex, BAR British Ser. 112 (Oxford, 1983); Sally White et al., "A Mid-Fifth Century Hoard of Roman and Pseudo-Roman Material from Patching, West Sussex," Britannia 30 (1999), 301-15.

48 David Hinton and Sally Worrell, "An Early Anglo-Saxon Cemetery and Archaeological Survey at Breamore, Hampshire, 1999-2006," Archaeological Journal 174:1 (2017), 68-145.

49 Bruce Eagles and Barry Ager, "A Mid 5th- to 6th-Century Bridle-Fitting of Mediterranean Origin from Breamore, Hampshire, England, with a Discussion of Its Local Context," in Bruc Ealles Well. Archaeological Essays Concerning the Peoples of North-West Europe in the First Millennium AD, ed. Marc Lodewijckx, Acta Archaeologica Lovaniensia, 15 (Leuven, 2004), pp. 87-96. 
a pail of similar form, but undecorated, was in a sword-bearing male burial in CLD 26-a burial that also included a copper alloy hanging bowl probably coming from a trade route with the British West. The coastal access point to the river Avon, upon which the Shallow's Farm site is located further upstream, lies behind the promontory of Hengistbury Head, visible on a clear day from the chalk ridge of the Isle of Wight.

The Isle of Wight and the Avon Valley were at the interface with the British West and Cornwall - areas that have produced ceramics that denoted trading links along the Atlantic seaboard to the Mediterranean. CLD 45, through the range of material present in her burial shows that she was the locus that demonstrated the mediation of relationships between two powerful trading regions - her burial, the largest and most substantial of those excavated, faces out towards the west of Britain and to the Atlantic seaboard trading routes, not east back towards Kent and Francia. Her burial was the visual demonstration of a north European network of associations in the 6th century.

\section{Conclusions}

Variations on the theme of female embodiment securing links and rights to landscape are a recurring and welcome theme in recent discussions of the archaeological and documentary evidence. This might be taken to display as a more generalised trend to now consider the actualities and choices in past peoples' lives. Duncan Sayer has argued that female burials with children mark out a system of dynamic investment, although whether married women moved to be near their female kin in the patrilocal residence around the time of birth might also be considered as an interpretation of female/child double burials. ${ }^{50}$ Whether we should consider clusters of female burials in a cemetery as single kin group or an assemblage of exogamous women would bear further investigation. Helena Hamerow considers the interconnections between gender and sacral authority and concludes that

the small number of royal nuns and abbesses who figure so prominently in written accounts of the Conversion were part of a wider, undocumented change in the role of women that began several decades before the

$50 \quad$ Duncan Sayer, "Sons of Athelings Given to the Earth: Infant Mortality within Anglo-Saxon Mortuary Geography," Medieval Archaeology 58:1 (2014), 78-103; Brooke A. Seelza, "Female Mobility and Postmarital Kin Access in a Patrilocal Society," Human Nature 22 (2011), $377-93$. 
founding of the first female houses. It is argued that these well-furnished graves reflect a new investment in the commemoration of females who came to represent their family's interests in newly acquired estates and whose importance was enhanced by their ability to confer supernatural legitimacy onto dynastic claims. ${ }^{51}$

A clear example of such a dual purpose may be surmised for the woman in the richly furnished 7 th-century grave in the square enclosure from Street House, Loftus, Cleveland - a site on a headland above the trading routes along the north east coast. ${ }^{52} \mathrm{~A}$ similar situation may be discerned for the woman excavated in 186o during the construction of the windmill at Sarre, here above the Wantsum Channel on the safe navigable route between Thanet and the mainland of Kent. ${ }^{53}$

I have argued that this is only a more visible result of a much earlier and widespread trend that was instrumental in confirming territorial and trading hegemonies in the 6th century. It is proposed that the female role in political networks, previously facilitated by marriage, is re-affirmed by their new role within minsters, as guardians and administrators of land and wealth. The 6thcentury burials can be read as making places and networks permanent within the spatial strategies of state formation.

Entry into a convent was not necessarily an alternative to marriage, but rather an adaptation by removing them from the market at the point at which they were no longer useful in this arena. Their next role was as landholders for the kin group, to maintain wealth for that group, in the knowledge that their position and status would be sufficient to fulfil this essential role. This is not to suggest a role as surrogate men, but a deployment and extension of their accepted gender identity set by the precedents of the 6th century.

The gender identity of females, as a category rather than through individual attributes, was important to confirm the interrelationships necessary for the claiming of territory. This could be achieved through marriage, which could operate seemingly at any age of the individual, with the femaleness of the body being all that was necessary. The construction of place, as known to people within the community and those visiting or passing by, was confirmed through

$5^{1} \quad$ Helena Hamerow, "Furnished Female Burial in Seventh-Century England: Gender and Sacral Authority in the Conversion Period," EME 24:4 (2016), 423-47, at p. 423.

52 Stephen Sherlock, A Royal Anglo-Saxon Cemetery at Street House, Loftus, North-East Yorkshire, Tees Archaeology Monograph 6 (Hartlepool, 2012).

53 John Brent, "Account of the Society's Researches in the Saxon Cemetery at Sarre," Arch. Cant. 5 (1863), 305-21. 
the placing of richly vested female burials at strategic nodes within networks of links over space. Most recently Kate Mees has noted the placement of highstatus female burials adjacent to long-distance ridge-top droveways in Wessex in the 7 th century. ${ }^{54}$

Females were emblematic and the embodiment of networks over space. Central to this construct, it is argued, was the formal agreement of marriage, which itself could become flexible regarding those involved and the requirements of the political circumstances. The woman in grave 45 at Chessell Down marked the sea-born interface between the Anglo-Saxon world, and its links to the east, with those polities to the west, themselves arguably already linked to the eastern Mediterranean by the 6th century. These women were not there by chance, but their presence does suggest parity with the status of weapon bearing men. Those men, as agents of a distant king, could have imposed their regime by force to extract trade tribute and surpluses. That, in the mid-6th century, it was also crucial to have the ideological status of females allied to their regimes of control perhaps offers precursors for the role of elite women in the early church of the 7 th century.

\section{Acknowledgements}

This paper is a re-working of a presentation made at the European Association of Archaeologists conference in Oslo, Norway in 2011. The session was concerned with the scientific evidence for female mobility.

The data referred to in the text is held in the database of the Beyond the Tribal Hidage project. This database from the Leverhulme Trust funded project (2006-9 at UCL Institute of Archaeology) holds records of the burials of 12,000 individuals and their 28,000 associated artefacts from over 600 burial sites in southern Britain south of the river Thames valley (data to 2017 and freely available yo download from https://www.ucl.ac.uk/early-medieval-atlas/map-data/ beyond-tribal-hidage-data). Barbara Yorke was an esteemed and active member of the advisory group, and gave invaluable support to the completion of the project in the aftermath of the untimely death of Martin Welch in 2011.

Thanks to Sarah Semple, Eleanor Dare, Stuart Brookes and Nick Stoodley for comments on earlier drafts and for highlighting omissions and errors. Remaining errors and misconceptions are mine alone.

54 Kate Mees, Burial, Landscape and Identity in Early Medieval Wessex (Woodbridge, 2019), pp. $67-73$. 